\title{
RAUHALAN HYVÄ SANOMA
}

Rauhala, L. 1990. Humanistinen psykologia. Helsinki. Yliopistopaino.

S ven Krohnin fenomenologinen koulukunta $S$ on tuottanut suomalaisen filosofian taivaalle useita kiintotähtiä. Krohnin Turun koulun kasvatteja ovat $\mathrm{mm}$. Lauri Routila, Matti Juntunen ja Lauri Mehtonen vain muutamia mainitakseni. Myös Lauri Rauhala (s. 1914) kuuluu kirkkaimpien joukkoon.

Rauhalan laaja tuotanto ulottuu 50-luvun alusta 90-luvulle. Hän on kirjoittanut niin artikkeleita, yhteisjulkaisuja, kirjoja kuin poleemisia keskustelupuheenvuoroja alansa aktuelleihin kysymyksiin. Rauhalan bibliografia käsittää tähän mennessä lähes sata eritasoista julkaisua. Miten siis luonnehtia yleisesti Rauhalan työtä ja erityisesti käsillä olevaa Rauhalan uusinta teosta?

Rauhalan työn yleinen luonnehdinta ei voi tässä tulla kysymykseen kuin pinnallisesti. Fenomenologisesta perusotteesta ja kiinnostuksesta 190 psykologiaan Rauhala on laajentanut näkemys- tään kohti erityistieteellisiä ongelmanasetteluja. Vaikka hänen kiinnostuksensa ja tutkimuskohteensa ovat olleet psykologian alalta, hänellä on sanottavaa oikeastaan kaikkiin ihmistieteisiin. Keskeisintä Rauhalan ajattelulle on filosofisen antropologian kuin myös filosofian perusongelma: mikä on ihminen? Tästä syystä Rauhalaa onkin pidettävä ensisijaisesti filosofina.

Käsillä olevan teoksen viimeisessä esseessä "Mitä filosofia minulle on" Rauhala kertoo omasta tiestään Jubo Hollon ja Eino Kailan johtamista kasvatuspsykologian ja filosofian opinnoista Suomen ensimmäiseen kliinisen psykologin virkaan Nikkilän sairaalaan ja sitä kautta kohti akateemista filosofian harrastusta. Työssään psykologina Rauhala joutui yhä uudestaan kysymään ihmistä selittävien oppien osuvuutta ja opeista johdettujen käytäntöjen toimivuutta. Tästä omakohtaisesti koetusta kirja saa terävyytensä. 
H umanistinen psykologia on yhdentoista esseen kokoelma. Humanistisen psykologian suuntaus ei aikuiskasvattajille ole suinkaan tuntematon. Tunnetuksi sitä on tehnyt varsinkin Rogers (1961). Vaikka Rauhalan kirja lähtee fenomenologian juurilta, se ei rajoitu niihin. Esseitä yhdistävää teema on humanististen tieteiden tieteenfilosofian kehitteleminen ja teema toistuu eri muodoissa läpi koko teoksen. Joskus samoihin asioihin palataan eri yhteyksissä. Tämä ei ole haitaksi, sillä näin peruskysymykset saavat sisältöään. Esseiden järjestys on ajateltu sellaiseksi, että fenomenologiseen käsitteistön perehtymätönkin saa otteen tarkastelluista teoreettisista ja käytännöllisistä kysymyksistä.

Rauhala on pyrkinyt esitystavassaan yli akateemisen kuivakkuuden. Esitystapa palvelee näin laajempaa lukijakuntaa ja kirjan tavoitetta: herätteiden antoa. Laajan lukijakunnan ja herätteiden annon toivossa kummastuttaa, ettei kirjassa ole sen paremmin lähdeluetteloa kuin viitteitä lisälukemiseksikaan. Joissain kohdissa lähdeviite on annettu tekstin sisällä, mutta akateemiseen kuivakkuuteen tottuneena tunnen jääneeni kiinnostavien aiheiden ja humanistisen psykologian peräkamareiden ulkopuolelle. Siitäkin huolimatta, että Rauhalan kirjoitus on sinänsä näkemyksellistä.

Muotoseikan ei saa kuitenkaan antaa häiritä paneutumista kirjan toisiinsa kietoutuneisiin peruskysymyksiin: ihmisen, ymmärtämisen ja merkityksen ongelmiin ihmistieteissä. Teoksen lukemista auttaa, kun muistaa Rauhalan pitkän kokemuksen ihmistieteiden peruskysymysten tutkijana, valaisijana ja psykologiatieteen vonkamiehen. Rauhala asettuu kriittiseen suhteeseen vallitseviin koulupsykologisiin oppeihin. Poimin seuraavassa vain erään kiinnostavan ajatuskulun.

K ritiikiltä ei kirjassa säästy behaviorismi eikä toimintateoria, vaan Rauhala laskee ne toistensa vastineiksi. Humanistisen psykologian eräs sanoma on, että toisin kuin behavioristisessa tai toiminnan tutkimussuuntautumisessa tarvitaan kokonaan uudenlaista suhtautumista ihmisen tajunnan ja merkityksen ongelman tutkimiseen. Rauhalan mukaan tajunnallisia merkityssuhteita ei voida jäännöksettä ymmärtää ulkoisen toiminnan heijastumina. Rauhalan mukaan tässä samaistamisessa on kyseessä looginen virhe: 'On kirkkaasti tiedostettava, että tutkivaa järjestelmää eli ajatusoperaatioita ei voida tutkia samoin käsittein kuin sen kohteena olevaa käyttäytymistä."' Behavioristisen asenteen kohdalla Rauhalaa kau- histuttaa se ihmisen esineellistäminen, jota numeroiden sokerikuorrutus luo: 'Numeroiden käytössä on suorastaan maagisia vivahteita." Kirja on puheenvuoro - ei metodiopas, joka tarjoaisi selvän vaihtoehdon edellisille suuntauksille. Johonkin se kuitenkin antaa osviittaa.

Thmistieteiden ja sovelletun käytännön liian kapea-alainen näkemys ihmisestä on saanut Rauhalan ponnistelemaan "erään hyvin perusteltavissa olevan holistisen ihmiskäsityksen" puolesta. Ihmisen kokonaisuudesta puhuessaan Rauhala sanoutuu irti ihmisen luonnontieteellisestä käsittämistavasta. Rauhala jakaa ihmisen kokonaisuuden kolmeen olemuspuoleen: Ihminen todellistuu tajunnallisuutena, kehollisuutena ja situationaalisuutena. Tajunnallisuus on karkeistaen ihmisen psyykkis-henkinen olemassaolo, kehollisuus ihmisen biologinen kokonaisuus ja situationaalisuus oma elämäntilanne. Nämä olemuspuolet olisi otettava huomioon niin ihmistutkimuksessa kuin ihmistyössäkin.

Samalla kun Rauhalan tematisointi auttaa ymmärtämään oppivaa ihmistä, se asettaa vaatimuksia eritoten aikuiskasvatuksen käytännölle. Miten esimerkiksi ottaa huomioon koulutuksessa ihmisten eri olemuspuolet? Ihminen ei ole pelkkä kognitiota, eikä ihmisten erilaisten situaatioiden huomioiminen ole helppoa. Erääksi ratkaistavaksi perusprobleemaksi aikuiskasvatuksen käytännön ja elinikäisen koulutuksen kannalta nouseekin yksityisen ihmisen elämäntilanteisuus: Miten auttaa ihmistä todellistumaan suhteessa opinnolliseen ajattelutapaan? Näin kirjaa lukiessa olen löytävinäni Rauhalan sanoista opetuksen: varsinkin tänä päivänä käytännön koulumiehenkin olisi oltava filosofin kaltainen pystyäkseen tarpeelliseen oman toimintansa reflektioon.

Osin Humanistinen psykologia toistaa Rauhalan aiempia pohdintoja. Akateemiseen kuivakkuuteen tottuneena pidän Rauhalan kirjaa Ihmiskäsitys ihmistyössä (1983) systemaattisempana esityksen nyt esillä olevista teemoista. Ero kirjojen välillä on osin niiden erilaisissa tavoitteissa. Käsillä olevan on tarkoitus herättää, toisen, tämän lisäksi, myös toimia oppikirjana. Niille koulumiehille, joita teknistyneen aikuiskasvatuksen käytännössä kiinnostaa vielä aikuiskasvatuksen peruskysymykset, saattaa Rauhalan hyvä sanoma tuottaa sen kumman tunteen, jota Rauhalan opettaja, Eino Kaila (1990, 551), on kuvannut omalaatuiseksi evidenssiksi " jolloin oma sisäinen elämäntajumme meille todistaa: "Niin se on, sellainen on ihminen!" 